\title{
TEORI KEADILAN DALAM PERSPEKTIF FILSAFAT HUKUM DAN ISLAM
}

\author{
Muhammad Kurniawan Budi Wibowo \\ Institut Islam Mamba’ul ‘Ulum Surakarta \\ Mkbwsolo1@yahoo.com
}

\begin{abstract}
The existence of Islamic law in the world is to regulate human life, both as a person and as a member of society in order to behave according to the wishes of the Creator. This is different from the general concept of law which is only intended to regulate human life as members of society or in other word the law exists because of the conflict of human interest. Among the problems in the philosophy of Islamic law, the most frequent discourse is about the issue of justice in relation to the law. This is because the law or regulation must be fair, but in fact it is often not. This paper will describe this issue of justice from the perspective of legal philosophy and Islam. In the perspective of legal philosophy, the author will only parse the theory of justice Aristotle and John Rawl. Whereas in the perspective of Islamic legal philosophy, the author will parse the theory of the Muktazilah and Asyariyah divine justice, and the Islamic Maqasyid Theory as the ideals of Islamic legal social justice.
\end{abstract}

Keywords : The Philosophy, Islamic Law, Justice.

\section{PENDAHULUAN}

Eksistensi hukum Islam di dunia adalah untuk mengatur kehidupan manusia, baik selaku pribadi maupun selaku anggota masyarakat agar dapat bertingkah laku sesuai dengan kehendak Sang Khalik. Ini berbeda dengan konsepsi hukum pada umumnya yang hanya ditujukan untuk mengatur kehidupan manusia selaku anggota masyarakat (odening van het social eleven). Artinya adanya masyarakat adalah yang menjadikannya adanya hukum ( ubi societas ibi ius) sehingga hukum itu ada (raison d'etre) karena adanya conflicts of human interest. Dari hal ini terlihat bahwa konsepsi hukum pada umumnya adalah karena adanya interaksi antara manusia yang satu dengan yang lainnya, adapun aturan yang hanya berkaitan dengan kehidupan pribadi tidak dinamakan hukum. Aturan tersebut dikenal dengan norma.1

\footnotetext{
${ }_{1}$ Abdul Ghofur Anshori,Yulkarnain Harahab, 2008, Hukum Islam Dinamika dan Perkembangannya di Indonesia, Yogyakarta, Kreasi Total Media, hal 31.
} 
Evolusi filsafat hukum Islam, yang melekat dalam evolusi filsafat secara keseluruhan, berputar di sekitar problema tertentu yang muncul berulang -ulang. Di antara problema ini, yang paling sering menjadi diskursus adalah tentang persoalan keadilan dalam kaitannya dengan hukum. Hal ini dikarenakan hukum atau aturan perundangan harusnya adil, tapi nyatanya seringkali tidak.

Keadilan hanya bisa dipahami jika ia diposisikan sebagai keadaan yang hendak diwujudkan oleh hukum. Upaya untuk mewujudkan keadilan dalam hukum tersebut merupakan proses yang dinamis yang memakan banyak waktu. Upaya ini seringkali juga didominasi oleh kekuatan-kekuatan yang bertarung dalam kerangka umum tatanan politik untuk mengaktualisasikannya. 2 Orang dapat menganggap keadilan sebagai sebuah gagasan atau realitas absolut dan mengasumsikan bahwa pengetahuan dan pemahaman tentangnya hanya bisa didapatkan secara parsial dan melalui upaya filosofis yang sangat sulit. Atau orang dapat menganggap keadilan sebagai hasil dari pandangan umum agama atau filsafat tentang dunia secara umum. Jika begitu, orang dapat mendefinisikan keadilan dalam satu pengertian atau pengertian lain dari pandangan ini.

Walhasil diskursus tentang keadilan begitu panjang dalam lintasan sejarah filsafat hukum. Hal ini juga terjadi dalam filsafat hukum Islam dimana teori keadilan, atau sering juga disebut dengan teori maslahat, selalu menjadi topik yang tidak hentinya dikaji oleh para ahli filsafat hukum Islam (ushul fiqh), terutama pada saat membahas tentang persoalan maqashid tasyri' atau maqashid syari'ah.s Bahkan persoalan keadilan ini juga masuk dalam ranah teologi, terutama terkait dengan masalah keadilan ilahiyah dan tanggung jawab manusia yang memunculkan dua kelompok besar yaitu muktazilah dan asy’ariyah. Dalam

makalah ini, Penulis akan menguraikan tentang persoalan keadilan ini dari perspektif filsafat hukum dan Islam. Dalam perspektif filsafat hukum, Penulis hanya akan mengurai teori keadilan Aristoteles dan John Rawl. Sedangkan dalam perpektif filsafat hukum Islam, Penulis akan mengurai teori keadilan Ilahiyah Muktazilah dan Asyariyah, dan Teori Maqasyid Syariah sebagai cita keadilan sosial hukum Islam. Harapan penulis tulisan ini bisa menjadi alternatif argumentasi hukum para hakim pengadilan agama dalam menegakkan nilai-nilai keadilan dalam memeriksa, memutus dan menyelesaikan perkara.

\footnotetext{
2 Carl Joachim Friedrich,2004, Filsafat Hukum Perspektif Historis, Bandung, Nuansa dan Nusamedia, hal 239.

${ }_{3}$ Kemaslahatan dan keadilan menjadi inti dari hukum Islam. Ini diwujudkan dengan banyaknya ayat al- Quran yang berisi tentang kemaslahatan dan keadilan Diantaranaya, yaitu an-Nisaa':58; an-Nisaa':135; al-Maidah: 8; alAn'aam:90; dan asy-Syura:15.
} 


\section{PEMBAHASAN}

\section{A. Teori Keadilan Dalam Filsafat Hukum dan Islam}

Teori-teori Hukum Alam sejak Socretes hingga Francois Geny, tetap mempertahankan keadilan sebagai mahkota hukum. Teori Hukum Alam mengutamakan "the search for justice".. Terdapat macam-macam teori mengenai keadilan dan masyarakat yang adil. Teori-teori ini menyangkut hak dan kebebasan, peluang kekuasaan, pendapatan dan kemakmuran. Diantara teori- teori itu dapat disebut: teori keadilan Aristoteles dalam bukunya nicomachean ethics dan teori keadilan sosial John Rawl dalam bukunya a theory of justice.

\section{Teori Keadilan Aristoteles}

Pandangan-pandangan Aristoteles tentang keadilan bisa kita dapatkan dalam karyanya nichomachean ethics, politics, dan rethoric. Lebihkhususnya, dalam buku nicomachean ethics, buku itu sepenuhnya ditujukan bagi keadilan, yang, berdasarkan filsafat umum Aristoteles, mesti dianggap sebagai inti dari filsafat hukum nya, "karena hukum hanya bisa ditetapkan dalam kaitannya dengan keadilan". 5

Yang sangat penting dari pandanganya ialah pendapat bahwa keadilan mesti dipahami dalam pengertian kesamaan. Namun Aristoteles membuat pembedaan penting antara kesamaan numerik dan kesamaan proporsional. Kesamaan numerik mempersamakan setiap manusia sebagai satu unit. Inilah yang sekarang biasa kita pahami tentang kesamaan dan yang kita maksudkan ketika kita mengatakan bahwa semua warga adalah sama di depan hukum. Kesamaan proporsional memberi tiap orang apa yang menjadi haknya sesuai dengan kemampuannya, prestasinya, dan sebagainya. Dar i pembedaan ini Aristoteles menghadirkan banyak kontroversi dan perdebatan seputar keadilan.

Lebih lanjut, dia membedakan keadilan menjadi jenis keadilan distributif dan keadilan korektif. Yang pertama berlaku dalam hukum publik, yang kedua dalam hukum perdata dan pidana. Kedailan distributif dan korektif sama-sama rentan terhadap problema kesamaan atau kesetaraan dan hanya bisa dipahami dalam kerangkanya. Dalam wilayah keadilan distributif, hal yang penting ialah bahwa imbalan yang sama-rata diberikan atas pencapaian yang sama rata. Pada yang kedua, yang menjadi persoalan ialah bahwa ketidaksetaraan yang disebabkan oleh, misalnya, pelanggaran kesepakatan, dikoreksi dan dihilangkan.

Keadilan distributif menurut Aristoteles berfokus pada distribusi, honor, kekayaan, dan barang-barang lain yang sama-sama bisa didapatkan dalam masyarakat. Dengan mengesampingkan "pembuktian" matematis, jelaslah bahwa 
apa yang ada dibenak Aristoteles ialah distribusi kekayaan dan barang berharga lain berdasarkan nilai yang berlaku dikalangan warga. Distribusi yang adil boleh jadi merupakan distribusi yang sesuai degan nilai kebaikannya, yakni nilainya bagi masyarakat.6

Di sisi lain, keadilan korektif berfokus pada pembetulan sesuatu yang salah. Jika suatu pelanggaran dilanggar atau kesalahan dilakukan, maka keadilan korektif berusaha memberikan kompensasi yang memadai bagi pihak yang dirugikan; jika suatu kejahatan telah dilakukan, maka hukuman yang sepantasnya perlu diberikan kepada si pelaku. Bagaimanapun, ketidakadilan akan mengakibatkan terganggunya "kesetaraan" yang sudah mapan atau telah terbentuk. Keadilan korektif bertugas membangun kembali kesetaraan tersebut. Dari uraian ini nampak bahwa keadilan korektif merupakan wilayah peradilan sedangkan keadilan distributif merupakan bidangnya pemerintah.7

Dalam membangun argumennya, Aristoteles menekankan perlunya dilakukan pembedaan antara vonis yang mendasarkan keadilan pada sifat kasus dan yang didasarkan pada watak manusia yang umum dan lazim, dengan vonis yang berlandaskan pandangan tertentu dari komunitas hukum tertentu. Pembedaan ini jangan dicampuradukkan dengan pembedaan antara hukum positif yang ditetapkan dalam undang-undang dan hukum adat. Karena, berdasarkan pembedaan Aristoteles, dua penilaian yang terakhir itu dapat menjadi sumber pertimbangan yang hanya mengacu pada komunitas tertentu, sedangkan keputusan serupa yang lain, kendati diwujudkan dalam bentuk perundang -undangan, tetap merupakan hukum alamjika bisa didapatkan dari fitrah umum manusia. 8

\section{Keadilan Sosial ala John Rawls}

John Rawls dalam bukunya a theory of justice menjelaskan teori keadilan sosial sebagai the difference principle dan the principle of fair equality of opportunity. Inti the difference principle, adalah bahwa perbedaan sosial dan ekonomis harus diatur agar memberikan manfaat yang paling besar bagi mereka yang paling kurang beruntung.

Istilah perbedaan sosil-ekonomis dalam prinsip perbedaan menuju pada ketidaksamaan dalam prospek seorang untuk mendapatkan unsur pokok kesejahteraan, pendapatan, dan otoritas. Sementara itu, the principle of fair equality of opportunity menunjukkan pada mereka yang paling kurang mempunyai peluang untuk mencapai prospek kesejahteraan, pendapat dan otoritas. Mereka inilah yang harus diberi perlindungan khusus.

6Carl Joachim Friedrich,2004, Filsafat Hukum Perspektif Historis, Bandung, Nuansa dan Nusamedia, hal 25
7 Carl Joachim Friedrich,2004, Filsafat Hukum PerspektifHistoris, Bandung, Nuansa dan Nusamedia, hal. 26-27.
${ }_{8}$ Carl Joachim Friedrich,2004, Filsafat HukumPerspektifHistoris, Bandung, Nuansa dan Nusamedia, hal. 26-27. 
Rawls mengerjakan teori mengenai prinsip-prinsip keadilan terutama sebagai alternatif bagi teori utilitarisme sebagaimana dikemukakan Hume, Bentham dan Mill. Rawls berpendapat bahwa dalam masyarakat yang diatur menurut prinsip-prinsip utilitarisme, orangorang akan kehilangan harga diri, lagi pula bahwa pelayanan demi perkembangan bersama akan lenyap. Rawls juga berpendapat bahwa sebenarnya teori ini lebih keras dari apa yang dianggap normal oleh masyarakat. Memang boleh jadi diminta pengorbanan demi kepentingan umum, tetapi tidak dapat dibenarkan bahwa pengorbanan ini pertama - tama diminta dari orangorang yang sudah kurang beruntung dalam masyarakat.

Menurut Rawls, situasi ketidaksamaan harus diberikan aturan yang sedemikian rupa sehingga paling menguntungkan golongan masyarakat yang paling lemah. Hal ini terjadi kalau dua syarat dipenuhi. Pertama, situasi ketidaksamaan menjamin maximum minimorum bagi golongan orang yang paling lemah. Artinya situasi masyarakat harus sedemikian rupa sehingga dihasilkan untung yang paling tinggi yang mungkin dihasilkan bagi golongan orang-orang kecil. Kedua, ketidaksamaan diikat pada jabatan-jabatan yang terbuka bagi semua orang. Maksudnya supaya kepada semua orang diberikan peluang yang sama besar dalam hidup. Berdasarkan pedoman ini semua perbedaan antara orang berdasarkan ras, kulit, agama dan perbedaan lain yang bersifat primordial, harus ditolak.

Lebih lanjut John Rawls menegaskan bahwa maka program penegakan keadilan yang berdimensi kerakyatan haruslah memperhatikan dua prinsip keadilan, yaitu, pertama, memberi hak dan kesempatan yang sama atas kebebasan dasar yang paling luas seluas kebebasan yang sama bagi setiap orang. Kedua, mampu mengatur kembali kesenjangan sosial ekonomi yang terjadi sehingga dapat memberi keuntungan yang bersifat timbal balik (reciprocal benefits) bagi setiap orang, baik mereka yang berasal dari kelompok beruntung maupun tidak beruntung.9

Dengan demikian, prisip berbedaan menuntut diaturnya struktur dasar masyarakat sedemikian rupa sehingga kesenjangan prospek mendapat hal-hal utama kesejahteraan, pendapatan, otoritas diperuntukkan bagi keuntungan orang - orang yang paling kurang beruntung. Ini berarti keadilan sosial harus diperjuangkan untuk dua hal: Pertama, melakukan koreksi dan perbaikan terhadap kondisi ketimpangan yang dialami kaum lemah dengan menghadirkan institusi- institusi sosial, ekonomi, dan politik yang memberdayakan. Kedua, setiap aturan harus memosisikan diri sebagai pemandu untuk mengembangkan kebijakankebijakan untuk mengoreksi ketidak-adilan yang dialami kaum lemah. 


\section{Teori Keadilan Dalam Filsafat Hukum Islam}

\section{a. Keadilan ilahiyah: dialektika muktazilah dan asy'ariah}

Gagasan Islam tentang keadilan dimulai dari diskursus tentang keadilan ilahiyah, apakah rasio manusia dapat mengetahui baik dan buruk untuk menegakkan keadilan dimuka bumi tanpa bergantung pada wahyu atau sebaliknya manusia itu hanya dapat mengetahui baik dan buruk melalui wahyu (Allah SWT). Pada optik inilah perbedaanperbedaan teologis di kalangan cendekiawan Islam muncul. Perbedaan-perbedaan tersebut berakar pada dua konsepsi yang bertentangan mengenai tanggung jawab manusia untuk menegakkan keadilan ilahiah, dan perdebatan tentang hal itu melahirkan dua mazhab utama teologi dialektika Islam yaitu: mu`tazilah dan asy’ariyah.

Tesis dasar Mu’tazilah adalah bahwa manusia, sebagai yang bebas, bertanggung jawab di hadapan Allah yang adil. Selanjutnya, baik dan buruk merupakan kategorikategori rasional yang dapat diketahui melalui nalar yaitu, tak bergantung pada wahyu. Allah telah menciptakan akal manusia sedemikian rupa sehingga mampu melihat yang baik dan buruk secara obyektif. Ini merupakan akibat wajar dari tesis pokok mereka bahwa keadilan Allah tergantung pada pengetahuan obyektif tentang baik dan buruk, sebagaimana ditetapkan oleh nalar, apakah sang Pembuat hukum menyatakannya atau tidak. Dengan kata lain, kaum Mu`tazilah menyatakan kemujaraban nalar naluri sebagai sumber pengetahuan etika dan spiritual, dengan demikian menegakkan bentuk obyektivisme rasionalis. 10

Pendirian Mu`tazilah tentu mendapat tentangan. Kaum Asy'ariah menolak gagasan akal manusia sebagai sumber otonomi pengetahuan etika. Mereka mengatakan bahwa baik dan buruk itu adalah sebagaimana Allah tentukan, dan adalah angkuh untuk menilai Allah berdasarkan kategori-kategori yang diberikan-Nya untuk mengarahkan kehidupan manusia. Bagi kaum Mu'tazilah tidak ada cara, dalam batas-batas logika biasa, untuk menerangkan hubungan kekuasaan Allah dengan tindakan manusia. Lebih realistis untuk mengatakan bahwa segala sesuatu yang terjadi merupakan hasil kehendak-Nya, tanpa penjelasan atau pembenaran. Namun, penting untuk membedakan antara tindakan manusia yang bertanggung jawab dan gerakan-gerakan yang dinisbahkan kepada hukum-hukum alam. Tanggung jawab manusia bukan merupakan hasil pemilihan bebas, suatu fungsi yang, menurut Mu'tazilah, menentukan cara bertindak yang dihasilkan. Namun hanya Allah semata-mata yang menciptakan segala tindakan secara langsung. Tetapi, dalam beberapa tindakan, suatu kualitas tindakan sukarela digantikan kehendak Allah SWT, yang menjadikan seseorang sebagai wakil 
sukarela dan bertanggung jawab. Karenanya, tanggung jawab manusia merupakan hasil kehendak ilahiah yang diketahui melalui bimbingan wahyu. Kalau tidak, nilai-nilai tidak memiliki dasar selain kehendak Allah SWT yang mengenai nilai-nilai itu.11

Konsepsi Asy ariah tentang pengetahuan etika ini dikenal sebagai subyektivisme teistis, yang berarti bahwa semua nilai etika tergantung padaketetapan - ketetapan kehendak Allah SWT yang diungkapkan dalam bentuk wahyu yang kekal dan tak berubah. Kedua pendirian teologis tersebut berdasarkan pada penafsiran ayat-ayat AlQuran, yang mempunyai pandangan kompleks tentang peranan tanggung jawab manusia dalam mewujudkan kehendah ilahiah di muka bumi. Di satu pihak, al-Quran berisikan ayat-ayat yang mendukung penekanan Mu`tzilah pada tanggung jawab penuh manusia dalam menjawab panggilan bimbingan alamiah maupun wahyu. Di lain pihak, juga memiliki ayat-ayat yang dapat mendukung pandangan Asyariah tentang kemahakuasaan Allah SWT yang tak memberi manusia peranan dalam menjawab bimbingan ilahiah. Betapapun, Al-Quran mempertimbangkan keputusan dan kemahakuasaan ilahiah dalam masalah bimbingan.

Sesungguhnya, konsep bimbingan natural atau universal mempunyai implikasi-implikasi yang lebih luas daripada mempertunjukkan eksistensi kapasitas kemauan dalam jiwa manusia $_{12}$, dan membuktikan tanggung jawab manusia dalam mengembangkan pengertian tajam persepsi moral dan spiritual serta motivasi, yang akan membawa kepada penegakan keadilan di muka bumi. Nampak bahwa Al-Quran menganggap manusia seluruhnya sebagai satu bangsa berhubung dengan bimbingan unuversal sebelum bimbingan khusus melalui para Nabi diturunkan, dan dengan demikian menganggap mereka semua secara bersama-sama bertanggung jawab untuk menegakkan keadilan:

"Manusia adalah umat yang satu; maka Allah mengutus para Nabi, sebagai pemberi kabar gembira dan pemberi peringatan, dan Ia menurunkan bersama mereka Kitab denga benar, untuk memberi keputusan di antara manusia tentang perkara yang mereka perselisihkan. ${ }_{13}$

Berdasarkan bimbingan universal, maka dapat dibicarakan tentang dasar - dasar naturalmoral tingkah laku manusia di dalam Al-Quran. Ayat-ayat tersebut menunjuk kepada watak moral yang universal dan obyektif yang membuat semua manusia diperlakukan secara sama dan sama-sama bertanggung jawab kepada Allah. Dengan kata lain, perintah-perintah moral tertentu jelaslah didasarkan pada watak umum manusia dan dianggap sebagai terlepas dari keyakinan-

${ }_{11}$ Mumtaz Ahmad (ed), 1994, Masalah-Masalah Teori politik Islam, Bandung, Mizan, hal. 156 ${ }_{12}$ QS Asy-Syam (Ayat 7)

${ }_{13}$ QS Al-Baqarah (Ayat 213) 
keyakinan spiritual tertentu, meskipun semua bimbingan praktis pada akhirnya berasal dari sumber yang sama, yaitu, dari Allah. Karena itu, penting untuk menekankan dalam konteks al-Quran, bahwa gagasan keadilan teistis menjadi relevan dengan mapannya tatanan sosial, karena secara logis membangkitkan keadilan obyektif universal yang mendarah daging dalam jiwa manusia. Dalam satu ayat yang sangat penting artinya, AlQuran mengakui watak obyektif dan universalitas keadilan yang disamakan dengan perbuatan - perbuatan baik (kebajikan-kebajikan moral), yang mengatasi masyarakatmasyrakat agama yang berlainan dan memperingatkan umat manusia untuk "tampil dengan perbuatan-perbuatan baik":

"Untuk tiap-tiap umat di antara kamu (umat religius) Kami berikan aturan dan jalan (tingkah laku). Apabila Allah menghendaki, niscaya kamu dijadikan-Nya satu umat (berdasarkan• pada aturan dan jalan itu), tetapi, (ia tidak melakukan demikian). Allah hendak menguji kamu terhadap pemberian-Nya kepadamu. Oleh karena itu, berlombalombalah (yaitu, bersaing satu samalain) dalam berbuat baik. Karena Allah- lah kamu semua akan kembali, lalu Ia akan memberitahukan kepadamu (kebenaran) mengenai apa yang kamu perselisihkan itu.”. ${ }_{14}$

Terhadap suatu asumsi yang jelas dalam ayat ini bahwa semua umat manusia harus berusaha keras menegakkan suatu skala keadilan tertentu, yang diakui secara obyektif, tak soal dengan perbedaan keyakinan-keyakinan religius. Cukup menarik, manusia yang idael disebutkan sebagai menggabungkan kebajikan moral tersebut dengan kepasrahan religius yang sempurna. Bahkan, "barangsiapa menyerahkan diri kepada Allah, sedang ia berbuat baik, maka baginya pahala pada sisi Tuhannya, dan tidak ada kekhawatiran bagi mereka, dan tidak pula mereka ber-sedih hati”. ${ }_{15}$

Jelaslah, disini kita mempunyai dasar yang jelas untuk membedakan antara keadilan obyektif dan teistis, dimana keadilan obyektif diperkuat lagi oleh tindakan-religius kepatuhan kepada Allah. Dalam bidang keadilan obyektif universal, manusia di perlakukan secara sama dan memikul tanggung jawab yang sama untuk menjawab bimbingan universal. Lagi pula, tanggung jawab moral asasiah semua manusia pada tingkat bimbingan universal inilah yang membuatnya masuk akal untuk mengatakan bahwa Al-Quran menunjukkan sesuatu yang sama dengan pemikiran barat tentang hukum natural, yang merupakan sumber keadilan positif dalam masyarakat yang berdasarkan persetujuan yang tak di ucapkan atau oleh tindakan resmi. Karena Al-Quran mengakui keadilan teitis dan obyektif, maka mungkin untuk mengistilahkannya keadilan natural dalam 
arti yang dipakai oleh Aristoteles yaitu, suatu produk dari kekuatan natural bukan dari kekuatan sosial.

Mengakui Aristoteles, para sarjana seringkali menyamakan keadilan Ilahiah dengan keadilan natural, tetapi, tidak seperti pakar-pakar hukum natural yang memperhatikan hubungan keadilan dengan masyarakat, faqih - faqih memusatkan usaha mereka pada konsep keadilan dalam kaitannya dengan kehendak Tuhan dan menghubungkannya dengan nasib manusia. Alim-alim tersebut berpendapat bahwa keadilan Ilahiah merupakan tujuan akhir dari wahyu islam, yang diungkapkan dalam bentuk awalnya dalam hukum-hukum islam yang suci (syari’ah). ${ }_{16}$

\section{b. Maqashid Syariah: Cita Keadilan Sosial Hukum Islam}

Salah satu konsep penting dan fundamental yang menjadi pokok bahasan dalam filasafat hukum Islam adalah konsep maqasid at-tasyri' atau maqasid al- syariah yang menegaskan bahwa hokum Islam disyari'atkan untuk mewujudkan dan memelihara maslahat umat manusia. Konsep ini telah diakui oleh para ulama dan oleh karena itu mereka memformulasikan suatu kaidah yang cukup popular. "Di mana ada maslahat, di sana terdapat hukum Allah." ${ }_{17}$ Teori maslahat di sini menurut Masdar F. Masudi sama dengan teori keadilan sosial dalam istilah filsafat hukum.18

Adapun inti dari konsep maqasid al-syariah adalah untuk mewujudkan kebaikan sekaligus menghindarkan keburukan atau menarik manfaat dan menolak mudarat, istilah yang sepadan dengan inti dari maqasid al-syari'ah tersebut adalah maslahat, karena penetapan hukum dalam Islam harus bermuara kepada maslahat. Untuk memahami hakikat dan peranan maqasid al-syari'ah, berikut akan diuraikan secara ringkas teori tersebut.

Imam al-Haramain al-Juwaini dapat dikatakan sebagai ahli teori (ulama usul alfiqh) pertama yang menekankan pentingnya memahami maqasid al- syari'ah dalam menetapkan hukum Islam. la secara tegas mengatakan bahwa seseorang tidak dapat dikatakan mampu menetapkan hukum dalam Islam, sebelum ia memahami benar tujuan Allah mengeluarkan perin-tah-perintah dan larangan-larangan-Nya.19

Kemudian al-Juwaini mengelaborasi lebih jauh maqasid al-syari'ah itu dalam hubungannya dengan illat dan dibedakan menjadi lima bagian, yaitu: yang masuk

\footnotetext{
${ }_{16}$ Mumtaz Ahmad (ed), 1994, Masalah-Masalah Teori politik Islam, Bandung, Mizan, hal. 157-162.

${ }_{17}$ Muhammad Sa'id Ramdan al-Buti, 1977, Dawabit al-Maslahah fi as-Syariah al-Islamiyah, Beirut, Mu'assasah ar-Risalah, hal. 12.

${ }_{18}$ Masdar F. Mas'udi, «Meletakkan Kembali Maslahat Sebagai Acuan Syari'ah» Jurnal Ilmu dan Kebudayaan

Ulumul Qur'an No. 3, Vol. VI Th. 1995. Hal. 97.

${ }_{19}$ Abd al-Malik ibn Yusuf Abu al-Ma' ali al-Juwaini,1400 H. Al-Burhan fi Usul al-Fiqh, Kairo, Dar al-Ansar, I:295.
} 
kategori daruriyat (primer), al-hajat al-ammah (sekunder), makramat (tersier), sesuatu yang tidak masuk kelompok daruriyat dan hajiyat, dan sesuatu yang tidak termasuk ketiga kelompok sebelumnya.20

Dengan demikian pada prinsipnya al-Juwaini membagi tujuan tasyri' itu menjadi tiga macam, yaitu daruriyat, hajiyat dan makramat (tahsiniyah).

Pemikiran al-Juwaini tersebut dikembangkan oleh muridnya, al-Gazali. Al-Gazali menjelaskan maksud syari'at dalam kaitannya dengan pembahasan tema istislah.21

Maslahat menurut al-Gazali adalah memelihara agama, jiwa, akal, keturunan dan harta.22

Kelima macam maslahat di atas bagi al-Gazali berada pada skala prioritas dan urutan yang berbeda jika dilihat dari sisi tujuannya, yaitu peringkat primer, sekunder dan tersier. ${ }_{23}$ Dari keterangan ini jelaslah bahwa teori maqasid al-syari'ah sudah mulai tampak bentuknya.

Pemikir dan ahli teori hukum Islam berikutnya yang secara khusus membahas maqasid al-syari'ah adalah Izzuddin ibn Abd al-Salam dari kalangan Syafi'iyah. Ia lebih banyak menekankan dan mengelaborasi konsep maslahat secara hakiki dalam bentuk menolak mafsadat dan menarik manfaat.24

Menurutnya, maslahat keduniaan tidak dapat dilepaskan dari tiga tingkat urutan skala prioritas, yaitu: daruriyat, hajiyat, dan takmilat atau tatimmat. 25

Lebih jauh lagi ia menjelaskan, bahwa taklif harus bermuara pada terwujudnya maslahat manusia, baik di dunia maupun di akhirat.26

Pembahasan tentang maqasid al-syari'ah secara khusus, sistematis dan jelas dilakukan oleh al-Syatibi dari kalangan Malikiyah. Dalam kitabnya al- Muwafaqat yang sangat terkenal itu, ia menghabiskan lebih kurang sepertiga pembahasannya mengenai maqasid al-syari'ah. Sudah tentu, pembahasan ten- tang maslahat pun menjadi bagian yang sangat penting dalam tulisannya. la secara tegas mengatakan bahwa tujuan utama Allah menetapkan hukum- hukum-Nya adalah untuk terwujudnya maslahat hidup manusia, baik di dunia maupun di akhirat. Karena itu, taklif dalam bidang hukum harus mengarah pada dan merealisasikan terwujudnya tujuan hukum tersebut. 27

Seperti halnya ulama sebelumnya, ia juga membagi urutan dan skala prioritas maslahat menjadi tiga urutan peringkat, yaitu daruriyat, hajiyat, dan

\footnotetext{
${ }_{20}$ Abd al-Malik ibn Yusuf Abu al-Ma’ali al-Juwaini,1400 H. Al-Burhan fi Usul al-Fiqh, Kairo, Dar al-Ansar, II: $923-$ 930.

${ }_{21}$ Al-Gazali, 1412 H, al-Mustasfa min Ilm al-Usul, Kairo, al-Amiriyah, hal. 250 dan seterusnya.

${ }_{22} \mathrm{Al}-$ Gazali, $1412 \mathrm{H}$, al-Mustasfa min Ilm al-Usul, Kairo, al-Amiriyah, hal. 251.

${ }_{23}$ Al-Gazali, 1412 H, al-Mustasfa min Ilm al-Usul, Kairo, al-Amiriyah, hal. 251

${ }_{24}$ Izzuddin ibn Abd al-Salam, Qawaid al-Ahkam fi Masalih al-Anam, Kairo, al-Istiqamat, t. t, I:9.

25 Izzuddin ibn Abd al-Salam, Qawaid al-Ahkam fi Masalih al-Anam, Kairo, al-Istiqamat, t.t II:60-62

26 Izzuddin ibn Abd al-Salam, Qawaid al-Ahkam fi Masalih al-Anam, Kairo, al-Istiqamat, t.t II:60-62

${ }_{27}$ Al-Syatibi, al-Muwafaqat fi Usul al-Syari'ah, Kairo, Mustafa Muhammad, t. t,) II:4.
} 
tahsiniyat.28

Yang dimaksud maslahat menurutnya seperti halnya konsep al-Gazali, yaitu memelihara lima hal pokok, yaitu: agama, jiwa, akal, keturunan dan harta. ${ }_{2}$ Konsep maqasid al-syari'ah atau maslahat yang dikembangkan oleh al-Syatibi di atas sebenarnya telah melampaui pembahasan ulama abad-abad sebelumnya. Konsep maslahat al-Syatibi tersebut melingkupi seluruh bagian syari'ah dan bukan hanya aspek yang tidak diatur oleh nas. Sesuai dengan pernyataan al- Gazali, al-Syatibi merangkum bahwa tujuan Allah menurunkan syari'ah adalah untuk mewujudkan maslahat. Meskipun begitu, pemikiran maslahat al-Syatibi ini tidak seberani gagasan atTufi. 30

Pandangan at-Tufi mewakili pandangan yang radikal dan liberal tentang maslahat. 31

At-Tufi berpendapat bahwa prinsip maslahat dapat membatasi (takhsis) Alquran, sunnah dan ijma' jika penerapan nas Alquran, sunnah dan ijma' itu akan menyusahkan manusia. 32

Akan tetapi, ruang lingkup dan bidang berlakunya maslahat at-Tufi tersebut adalah mu'amalah.

Sejak awal syari'ah Islam sebenarnya tidak memiliki tujuan lain kecuali kemaslahatan manusia. Ungkapan standar bahwa syari'ah Islam dicanangkan demi kebahagiaan manusia, lahir-batin; duniawi-ukhrawi, sepenuhnya mencerminkan maslahat. Akan tetapi keterikatan yang berlebihan terhadap nas, seperti dipromosikan oleh faham ortodoksi, telah membuat prinsip maslahat hanya sebagai jargon kosong, dan syari'ah-yang pada mulanya adalah jalan-telah men• jadi jalan bagi dirinya sendiri. 34

Hukum haruslah didasarkan pada sesuatu yang harus tidak disebut hukum, tetapi lebih mendasar dari hukum. Yaitu sebuah sistem nilai yang dengan sadar dianut sebagai keyakinan yang harus diperjuangkan: maslahat, keadilan. Proses pendasaran hukum atas hukum hanya bisa dimengerti dalam konteks formal, misalnya melalui caraqiyas. Akan tetapi, seperti diketahui, qiyas haruslah dengan illat, sesuatu yang lebih merupakan patokan hukum, bukan hukum itu sendiri.

\footnotetext{
${ }_{28}$ Al-Syatibi, al-Muwafaqat fi Usul al-Syari'ah, Kairo, Mustafa Muhammad, t. t, ) II:4.

29 Al-Syatibi, al-Muwafaqat fi Usul al-Syari'ah, Kairo, Mustafa Muhammad, t. t,) II:5.

${ }_{30}$ Nur A. Fadhil Lubis, 1995, Hukum Islam dalam Kerangka Teori Fikih dan Tata Hukum Indonesia, Medan, Pustaka Widyasarana, hal. 34-35.

${ }_{31}$ Nur A. Fadhil Lubis, 1995, Hukum Islam dalam Kerangka Teori Fikih dan Tata Hukum Indonesia, Medan, Pustaka Widyasarana, hal. 34-35

${ }_{32}$ Najmuddin at-Tufi, Syarh al-Hadis Arba'in an-Nawaiyah dalam Mustafa Zaid. 1954. al-Maslahat fi at- Tasyri' $i$ al-Islami wa Najmuddin at-Tufi, Mesir, Dar al-Fikr al-Arabi, hal. 46.

${ }_{33}$ Najmuddin at-Tufi, Syarh al-Hadis Arba'in an-Nawaiyah dalam Mustafa Zaid. 1954. al-Maslahat fi at- Tasyri' $i$ al-Islami wa Najmuddin at-Tufi, Mesir, Dar al-Fikr al-Arabi, hal. 48.

${ }_{34}$ Masdar F. Mas'udi, «Meletakkan Kembali Maslahat Sebagai Acuan Syari'ah» Jurnal Ilmu dan Kebudayaan Ulumul Qur'an No. 3, Vol. VI Th. 1995, hal. 94.
} 
Akan tetapi itulah struktur pemikiran hukum Islam selama ini. Oleh sebab itu tidak mengherankan apabila dunia pemikiran hukum Islam ditandai oleh ciri dan watak yang sangat patut dipertanyakan.35

Tidak mengherankan apabila wajah fiqh selama ini tampak menjadi dingin, suatu wajah fiqh yang secara keseluruhan kurang menunjukkan pemihakan (engagement) terhadap kepentingan masyarakat manusia.36

Dengan demikian, jelas bahwa yang fundamental dari bangunan pemikiran hukum Islam adalah maslahat, maslahat manusia universal, atau- dalam ungkapan yang lebih operasional"keadilan sosial". Tawaran teoritik (ijtihadi) apa pun dan bagaimana pun, baik didukung dengan nas atau pun tidak, yang bisa menjamin terwujudnya maslahat kemanusiaan, dalam kacamata Islam adalah sah, dan umat Islam terikat untuk mengambilnya dan merealisasikannya. Sebaliknya, tawaran teoritik apa pun dan yang bagaimana pun, yang secara meyakinkan tidak mendukung terjaminnya maslahat, lebih lebih yang membuka kemungkinan terjadinya kemudaratan, dalam kacamata Islam, adalah fasid, dan umat Islam secara orang perorang atau bersama-sama terikat untuk mencegahnya.37

Dengan paradigma di atas, kaidah yang selama ini dipegang oleh dunia figh yang berbunyi: Apabila suatu hadis teks ajaran telah dibuktikan kesahihannya, itulah mazhabku, secara meyakinkan perlu ditinjau kembali. Kaidah inilah yang secara sistematis telah menggerakkan dunia pemikiran, khususnya pemikiran hukum, dalam Islam lebih mengutamakan bunyi harfiyah nas daripada kandungan substansialnya. Atau, dalam dunia pemikiran figh, lebih mengutamakan - atau bahkan hanya memperhatikan- bunyi ketentuan legal-formal, daripada tuntutan maslahat (keadilan), yang notabene merupakan jiwanya. Sebagai gantinya, kita perlu menegakkan kaidah yang berbunyi: jika tuntutan maslahat, keadilan, telah menjadi sah- melalui kesepakatan dalam musyawarah- itulah mazhabku.s8

Dengan tawaran kaidah yang lebih menekankan pada substansi, yaitu maslahat-keadilan, bukan berarti segi formal dan tekstual dari ketentuan hukum harus diabaikan. Ketentuan legalformal-tekstual yang sah, bagaimana pun, harus menjadi acuan tingkah laku manusia dalam kehidupan bersama, kalau tidak ingin menjadi anarki. Akan tetapi, pada saat yang sama, haruslah disadari sedalam-dalamnya bahwa patokan legal-formal dan tekstual hanyalah merupakan cara bagaimana cita maslahat, keadilan, itu diaktualisasikan dalam kehi

\footnotetext{
${ }_{35}$ Masdar F. Mas'udi, «Meletakkan Kembali Maslahat Sebagai Acuan Syari'ah» Jurnal Ilmu dan Kebudayaan Ulumul Qur'an No. 3, Vol. VI Th. 1995, hal. 94-95.

${ }_{36}$ Masdar F. Mas'udi, «Meletakkan Kembali Maslahat Sebagai Acuan Syari'ah» Jurnal Ilmu dan Kebudayaan Ulumul Qur'an No. 3, Vol. VI Th. 1995, hal. 96.

${ }_{37}$ Masdar F. Mas'udi, «Meletakkan Kembali Maslahat Sebagai Acuan Syari'ah» Jurnal Ilmu dan Kebudayaan Ulumul Qur'an No. 3, Vol. VI Th. 1995, hlm. 97.

${ }_{38}$ Masdar F. Mas'udi, «MeletakkanKembali Maslahat SebagaiAcuan Syari'ah» Jurnal Ilmu dan

Kebudayaan Ulumul Qur'an No. 3, Vol. VI Th. 1995, hlm. 97
} 
dupan nyata. Ini berarti bahwa ketentuan formal-tekstual, yang bagaimana pun dan datang dari sumber apa pun, haruslah selalu terbuka dan atau diyakini terbuka untuk, kalau perlu, diubah atau diperbarui sesuai dengan tuntutan maslahat, cita keadilan.

Apabila jalan pikiran di atas disepakati, secara mendasar kita pun perlu meninjau kembali pemahaman kita terhadap konsep usul fiqh tentang apa yang disebut qat'i (yang pasti dan tidak bisa diubah-ubah oleh ijtihad) dan zanni (yang tidak/kurang pasti dan bisa diubah-ubah oleh ijtihad) dalam hukum Islam. Figh selama ini mengatakan bahwa yang qat'i adalah apa-apa (hukum- hukum) yang secara sarih ditunjuk oleh nas Alquran/hadis Nabi. Sedangkan yang Zanni adalah apa-apa (hukum) yang petunjuk nasnya kurang/tidak sarih, ambigu dan mengan dung pengertian yang bisa berbedabeda.39

Sesungguhnya, yang qat'i dalam hukum Islam sesuai dengan makna harfiyahnya: sebagai sesuatu yang bersifat pasti, tidak berubah-ubah dan karena itu bersifat fundamental- adalah nilai maslahat atau keadilan itu sendiri, yang nota bene merupakan jiwanya hukum. Sedang yang masuk kategori zanni (tidak pasti dan bisa diubah-ubah) adalah seluruh ketentuan batang tubuh atau teks, ketentuan normatif, yang dimaksudkan sebagai upaya yang menerjemahkan yang qat'i (nilai maslahat atau keadilan) dalam kehidupan nyata. Sehingga kalau dikatakan bahwa ijtihad tidak bisa terjadi untuk daerah qat' $i$, dan hanya bisa dilakukan untuk hal-hal yang zanni, itu memang benar adanya. Cita "maslahat dan keadilan" sebagai hal yang qat'i dalam hukum Islam, memang tidak bisa-bahkan juga tidak perlu untuk dilakukan ijtihad guna menentukan kedudukan hukumnya, apakah wajib, mubah atau bagaimana.

Yang harus diijtihadi dengan seluruh kemampuan mujtahid adalah hal- hal yang zanni, yang tidak pasti, yang memang harus diperbarui terus-menerus sesuai dengan tuntutan ruang dan waktu yang juga terus bergerak. Yakni, pertama, definisi tentang maslahat, keadilan, dalam konteks ruang dan aktu nisbi dimana kita berada; kedua, kerangka normatif yang memadai sebagai pengejawantahan dari cita maslahat- keadilan dalam konteks ruang dan waktu tertentu; dan ketiga, kerangka kelembagaan yang memadai bagi sarana aktualisasi norma-norma maslahat-keadilan, seperti dimaksud pada poin pertama dan kedua, dalam realitas sosial yang bersangkutan.

Untuk mempermudah pemahaman, dapat dikemukakan satu ilustrasi syari’at zakat. Tujuan disyari’atkan zakat adalah jelas: terwujudnya keadilan sosial dan kesejahteraan bersama dengan prinsip yang kuat membantu yang lemah. Di

\footnotetext{
${ }_{39}$ MasdarF.Mas'udi, «Meletakkan Kembali MaslahatSebagaiAcuan Syari'ah» Jurnal Ilmu dan Kebudayaan Ulumul Qur'an No. 3, Vol. VI Th. 1995, hlm.97
} 
sini tidak ada keperluan sedikit pun untuk melakukan ijtihad guna menentukan hukumnya menegakkan keadilan sebagaimana dicita-citakan oleh konsep zakat tersebut. 40

Yang perlu dilakukan ijtihad adalah dalam hal-hal berikut ini: pertama, mendefinisikan keadilan sosial dan pemerataan kesejahteraan dalam konteks ruang dan waktu tertentu, misalnya konteks bangsa Indonesia dalam dasawarsa kini dan mendatang; kedua, berapa beban yang harus ditanggung oleh mereka yang mampu (miqdar al-zakah), atas basis kekayaan apa saja (mahall al-zakah), kapan harus dibayar (waqt al-ada), dan siapa-siapa serta dimana alamatnya yang secara riil dan definitif harus diuntungkan oleh zakat, dan sektor apa saja yang secara riil dan definitif harus didukung oleh dana zakat (masraf al-zakah), dan sebagainya; dan ketiga, kelembagaan apa saja yang seharusnya tersedia dalam realitas sosial politik Indonesia yang bisa mendukung terwujudnya keadilan sosial dengan zakat tersebut; bagaimana mekanisme pembentukannya, kerjanya dan kontrolnya.

Bagaimana ketentuan yang terdapat dalam teks ajaran atau dalam pendapat para ulama mengenai persoalan pada ketiga point tersebut, tidak ada yang qat'i. Semuanya zanni, dan karena itu bisa-bahkan tidak terelakkan untuk disesuaikan, diubah, kapan saja tuntutan maslahat-keadilan menghendaki. Misalnya, tentang amwal zakawi; tidaklah adil untuk zaman sekarang, kita hanya mengenakan pungutan sedekah wajib atas kurma dan anggur, sementara "kelapa sawit", apel, kopi, tembakau”, yang tidak kalah ekonomisnya, kita bebaskan begitu saja. J uga,

tidak adil kita kenakan beban sedekah wajib atas pendapatan sektor pertanian, sementara dari sektor industri dan jasa justru kita merdekakan.41

Demikian pula, tidak sesuai lagi dengan maslahat keadilan yang nyata kalau sabilillah, sebagai salah satu dari mustahik zakat, hanya didefinisikan dengan "tentara di medan perang melawan orang kafir", sementara aparat penegak hukum seperti polisi, jaksa, hakim dan pembela hukum, tetap kita letakkan di luar orbit missi ketuhanan untuk tegakkan orde keadilan. Lalu akibatnya kita semua tahu, rakyat cenderung melepaskan mereka dari tuntutan moral. Mereka sendiri cenderung merasa bebas dari tuntutan itu. Dengan meletakkan mereka pada barisan sabilillah, kita telah memberikan justifikasi dan sekaligus kepedulian

(kritik) sosial kita terhadap peran dan aktivitas mereka, dengan acuan nilai ketuhanan, keadilan. Kalau acuan hukum- juga hukum dalam kacamata Islam, yakni syari'at- adalah maslahat keadilan, pertanyaan yang akan segera muncul adalah, bagaimana "maslahat, atau keadilan" itu dapat didefinisikan, dansiapa

\footnotetext{
${ }_{40}$ Masdar F. Mas'udi, "Meletakkan Kembali Maslahat Sebagai Acuan Syari'ah" Jurnal Ilmu dan Kebudayaan Ulumul Qur'an No. 3, Vol. VI Th. 1995,hal. 97 -98.

${ }_{41}$ Masdar F. Mas'udi, "Meletakkan Kembali MaslahatSebagai AcuanSyari'ah" Jurnal Ilmudan Kebudayaan Ulumul Qur'an No.3, Vol. VI Th. 1995, hal. 98.
} 
punya otoritas untuk mendefinisikannya. Tidak syak lagi, pertanyaan ini sangat penting dan menentukan. Gagal menjawab pertanyaan ini, akan kembali berimplikasi untuk memperkatakan bahwa maslahat-keadilan sebagai tujuan syari,at (hukum), telah dijadikan tujuan bagi dirinya sendiri. Maslahat keadilan hanya jargon kosong belaka.

Untuk menjawab pertanyaan ini, terlebih dahulu perlu membedakan antara maslahat yang bersifat "individu subyektif" dengan maslahat yang bersifat "sosialobyektif". Maslahat yang bersifat individual-subyektif, adalah maslahat yang menyangkut kepentingan seseorang yang secara eksistensial bersifat independen, dan terpisah, dengan kepentingan orang lain. Dalam maslahat kategori ini, karena sifatnya yang sangat subyektif, yang berhak menentukan dan sekaligus sebagai hakimnya tentu saja adalah pribadi bersangkutan. Tidak ada kekuatan kolektif mana pun yang berhak menentukan apa yang secara personal-subyektif dianggap maslahat oleh seseorang.42

Sedangkan maslahat yang bersifat sosial-obyektif adalah maslahat yang menyangkut kepentingan orang banyak. Dalam hal ini, otoritas yang berhak memberikan penilaian yang dan sekaligus menjadi hakimnya tidak lain adalah orang banyak yang bersangkutan, melalui mekanisme syura untuk mencapai kesepakatan (ijma'). Jadi, apa yang disepakati oleh orang banyak dari proses pendefinisian maslahat melalui musyawarah itulah hukum yang sebenarnya. Kesepakatan orang banyak, di mana kita merupakan bagian daripadanya, itulah hukum tertinggi yang mengikat. Kalau dipertanyakan kedudukan hukum atau ketentuan-ketentuan legal-normatif yang ditawarkan oleh wahyu (teks Alquran atau hadis), kedudukannya adalah sebagai material yang juga dengan logika maslahat sosial yang obyektif, bukan dengan logika kekuatan atau kepercayaan yang subyektif,_-masih harus dibawa untuk ditentukan statusnya ke dalam lembaga permusyawaratan. Apabila kita berhasil membawanya sebagai bagian dari kesepakatan orang banyak, ia berfungsi sebagai hukum yang secara formal- positif mengikat. Akan tetapi, apabila gagal memperjuangkannya sebagai kesepakatan, daya ikatnya tentu saja hanya terbatas pada orang -orang yang mempercayainya. Dan daya ikat seperti ini paling jauh hanya bersifat moral-subyektif, tidak bisa sekaligus formal-obyektif.

Memang, dengan mempertaruhkan "maslahat dan sekaligus norma hukum yang bersumber padanya" pada ijma' lembaga syura, atau keputusan lembaga parlemen dalam terma ketata-negaraan modern, bukan tidak ada kelemahannya. Tidak jarang apa yang disebut kesepakatan lembaga syura, parlemen, ternyata

\footnotetext{
${ }_{22}$ Masdar F. Mas'udi, «Meletakkan Kembali Maslahat Sebagai Acuan Syari'ah» Jurnal Ilmu dan Kebudayaan Ulumul Qur'an No. 3, Vol. VI Th. 1995, hal. 99.
} 
hanya merupakan hasil rekayasa segelintir elit yang berkuasa. Akan tetapi inilah tantangan yang harus dihadapi oleh umat Islam, yang sebenarnya adalah juga tantangan bagi rakyat-manusia di mana pun mereka berada. Yakni, bagaimana mereka bisa mengusahakan tumbuhnya satu pranata kesepakatan umat, di mana rakyat- secara langsung atau melalui wakilnya- dapat mengemukakan pendapat dan pilihannya perihal tata-kehidupan yang menurut mereka lebih mencerminkan cita maslahat dan keadilan.43

\section{PENUTUP}

Sebagai penutup dari pembahasan ini, perlu dikemukakan kesimpulan- kesimpulan sebagai berikut : Pertama, keadilan dalam filsafat hukum menjadi landasan utama yang harus diwujudkan melalui hukum yang ada. Aristoteles menegaskan bahwa keadilan sebagai inti dari filsafat hukumnya. Baginya, keadilan dipahami dalam pengertian kesamaan, antara kesamaan numerik dan kesamaan proporsional. Kesamaan numerik mempersamakan setiap manusia sebagai satu unit. Kesamaan proporsional memberi tiap orang apa yang menjadi haknya sesuai dengan kemampuannya, prestasinya, dan sebagainya. Dia juga membedakan keadilan menjadi jenis keadilan distributif dan keadilan korektif. Yang pertama berlaku dalam hukum publik, yang kedua dalam hukum perdata dan pidana.

John Rawls dengan teori keadilan sosialnya menegaskan bahwa maka program penegakan keadilan yang berdimensi kerakyatan haruslah memperhatikan dua prinsip keadilan, yaitu, pertama, memberi hak dan kesempatan yang sama atas kebebasan dasar yang paling luas seluas kebebasan yang sama bagi setiap orang. Kedua, mampu mengatur kembali kesenjangan sosial ekonomi yang terjadi sehingga dapat memberi keuntungan yang bersifat timbal balik (reciprocal benefits) bagi setiap orang, baik mereka yang berasal dari kelompok beruntung maupun tidak beruntung.

Kedua, teori keadilan dalam Islam pertama kali didiskusikan sebagai persoalan teologi tentang keadilan ilahiyah yang melahirkan dua mazhab yaitu: mu`tazilah dan asy`ariyah. Mu`tazilah menyatakan bahwa manusia, sebagai yang bebas, bertanggung jawab di hadapan Allah SWTyang adil. Baik dan buruk merupakan kategori-kategori rasional yang dapat diketahui melalui nalar. Allah SWT telah menciptakan akal manusia sedemikian rupa sehingga mampu melihat yang baik dan buruk secara obyektif. Mu'tazilah dengan demikian menegakkan bentuk obyektivisme rasionalis. Sedangkan Asy`ariah mengatakan bahwa baik

\footnotetext{
${ }_{43}$ Masdar F. Mas'udi, «Meletakkan Kembali Maslahat Sebagai Acuan Syari'ah» Jurnal Ilmu dan Kebudayaan Ulumul Qur'an No. 3, Vol. VI Th. 1995
} 
dan buruk itu adalah sebagaimana Allah tentukan, dan adalah angkuh untuk menilai Allah SWTberdasarkan kategori-kategori yang diberikan-Nya untuk mengarahkan kehidupan manusia. Tanggung jawab manusia bukan merupakan hasil pemilihan bebas, namun hanya Allah semata-mata yang menciptakan segala tindakan secara langsung. Karenanya, tanggung jawab manusia merupakan hasil kehendak ilahiah yang diketahui melalui bimbingan wahyu. Konsepsi ini dikenal sebagai subyektivisme teistis. Di samping itu, teori keadilan juga menjadi landasan utama dalam filsafat hukum Islam, khususnya dalam pembahasan maqasid alsyariah yang menegaskan bahwa hukum Islam disyari'atkan untuk mewujudkan dan memeli-hara maslahat umat manusia. Teori maslahat di sini sama dengan teori keadilan sosial dalam istilah filsafat hukum. Teori ini pertama kali dikenalkan oleh Imam al-Haramain al-Juwaini lalu dikembangkan oleh muridnya, al-Gazali. Ahli teori hukum Islam berikutnya yang secara khusus membahas maqasid al-syari'ah adalah Izzuddin ibn Abd al-Salam dari kalangan Syafi'iyah. Dan pembahasan secara sistematis dan jelas dilakukan oleh al-Syatibi dari kalangan Malikiyah dalam kitabnya al-Muwafaqat. Di samping itu, at-Tufi juga ikut memberikan pandangan yang radikal dan liberal tentang maslahat.

\section{DAFTAR PUSTAKA}

Abdul Ghofur Anshori, Yulkarnain Harahab 2008, Hukum Islam Dinamika dan Perkembangan di Indonesia, Yogyakarta, Kreasi Total Media.

Abddul Ghofur Anshori, 2009, Filsafat Hukum, Yogyakarta, UGM Press.

Abd al-Malik ibn Yusuf Abu al-Ma'ali al-Juwaini,1400 H, Al-Burhan fi Usul al-Fiqh, Kairo, Dar al-Ansar.

Al-Gazali,1412 H, al-Mustasfa min Ilm al-Usul, Kairo, al-Amiriyah. Al-Syatibi, alMuwafaqat fi Usul al-Syari'ah, (Kairo, Mustafa Muhammad,t. t). Carl Joachim Friedrich, 2004, Filsafat Hukum Perspektif Historis, Bandung, Nuansa dan Nusamedia.

Izzuddin ibn Abd al-Salam, Qawaid al-Ahkam fi Masalih al-Anam (Kairo: al- Istiqamat, t. $\mathrm{t})$.

John Rawls, A Theory of Justice, London: Oxford University press, 1973, yang sudah diterjemahkan dalam bahasa indonesia oleh Uzair Fauzan dan Heru Prasetyo, Teori Keadilan, 2006, Yogyakarta, Pustaka Pelajar.

Mumtaz Ahmad (ed),1994, Masalah-Masalah Teori politik Islam, Bandung,Mizan. Muhammad Sa'id Ramdan al-Buti, Dawabit al-Maslahah fi as-Syariah alIslamiyah, (Beirut: Mu'assasah ar-Risalah,1977).

Masdar F. Mas'udi, "Meletakkan Kembali Maslahat Sebagai Acuan Syari’ah” Jurnal Ilmu dan Kebudayaan Ulumul Qur'an No. 3, Vol. VI Th. 1995. 
Nur A. Fadhil Lubis, Hukum Islam dalam Kerangka Teori Fikih dan Tata Hukum Indonesia (Medan :Pustaka Widyasarana,1995).

Najmuddin at-Tufi, Syarh al-Hadis Arba'in an-Nawaiyah dalam Mustafa Zaid. 1954. alMaslahat fi at-Tasyri'i al-Islami wa Najmuddin at-Tufi, Mesir: Dar al- Fikr al-Arabi.

Theo Huijbers,1995, Filsafat Hukum dalam Lintasan Sejarah, cet VIII, Yogyakarta, Kanisius. 